\title{
Photovoltaic Systems Growing: An Update
}

\author{
Ntumba Marc-Alain Mutombo \\ Department Electrical Engineering, Mangosuthu University of Technology, Durban, KwaZulu-Natal
}

\begin{abstract}
The photovoltaic (PV) technology as the third renewable energy (RE) generation source is growing faster than most of the RE technology due to intense research performed in this field. This last year has seen an important growing of PV technology in efficiency, cost, applications, capacity and economy. The global total solar PV installed capacity in 2018 is dominated by APAC (China included) with $58 \%$ of solar PV installed capacity, follows by Europe (25\%), America (15\%) and MEA (2\%). Even with a decline of $16 \%$ in 2018, the global solar PV market continue to be dominated by China with $44.4 \mathrm{GW}$ installed in 2018 against $52.8 \%$ GW in 2017. The 2018 solar PV outlook market forecast presents a growth of solar market with progressive slow down, from 2019 to 2023 over 5 years. Based on the predictions, the world could centre the Tetrawatts production capacity level by 2021 , only 3 years after reaching 0.5 TW level.
\end{abstract}

This paper is an update on the PV systems growing. Detailed summary on the evolution of PV cell structure, energy conversion, efficiency, cost, applications, environmental impact, capacity and economy are presented.

Keywords: Solar cell, Efficiency, Cost, Electrical energy, Growing, Environment, Economy

\section{INTRODUCTION}

The solar energy (SE) is one of RE source that is growing in production as well as in use. This is due mostly to his environmental and economic advantages that have allowed this technology the merit to be the third RE source after hydro and wind based on installed capacity [1]. The effective process of conversion of SE into electricity by solar cells is based on the proprieties of the semi-conductor material used in the manufacture of solar cell, the most important being the band gap, the absorption coefficient, the refractive coefficient, the electron affinity, the lattice constant, and the thermal expansion coefficient. The choice of semi-conductor material is based also on fact to make a solar cell with higher energetic efficiency at low cost. To realize that, many researches have been focus in the improvement of solar cell efficiency and cost by considering his environmental impact. Research and field results have proven that PV systems are clean energy sources for the environment and the price of this technology keep decreasing following Swanson's law.

\section{PHOTOVOLTAIC CELL STRUCTURE AND ENERGY CONVERSION}

The PV technology was born at Units States in 1954 with the development of the silicon PV cell made by Daryl Chapin, Calvin Fuller and Gerard Pearson at Bell labs. This cell was able to convert enough SE into electricity for house appliances [2]. The term PV referred to the operating mode of photodiode device in which the flow of current is entirely due to the transduced light energy. Based on their structure and operating mode, all PV devices are considered as some type of photodiode. Fig. 1 shows the schematic block diagram of a PV cell.

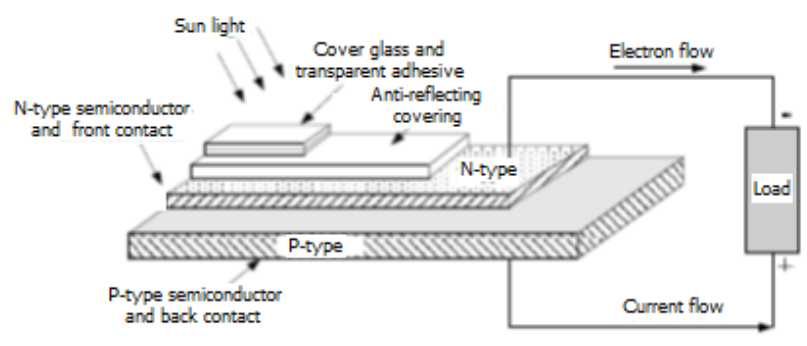

Fig. 1. Schematic block diagram of PV cell [3]

Most common materials used in the manufacturing of PV solar cells are monocrystalline silicone, polycrystalline silicon, amorphous silicon, cadmium telluride, and copper indium gallium selenide/sulphide [4]. Table 1 gives some properties of semiconductor materials mostly used in photovoltaic applications.

Table 1. Properties of the principal semiconductors with photovoltaic applications [5]

\begin{tabular}{|c|c|c|c|}
\hline Materials & $\begin{array}{c}\text { Bandgap } \\
\text { Eg (eV) }\end{array}$ & $\begin{array}{c}\text { Absorption } \\
\text { coefficient }\end{array}$ & $\begin{array}{c}\text { Refractive } \\
\text { coefficient }\end{array}$ \\
\hline $\mathrm{c}-\mathrm{Si}$ & $1.12(\mathrm{i})$ & 11.9 & 3.97 \\
\hline $\mathrm{GaAs}$ & $1.42(\mathrm{~d})$ & 13.18 & 3.90 \\
\hline $\mathrm{InP}$ & $1.35(\mathrm{~d})$ & 12.56 & 3.60 \\
\hline $\mathrm{a}-\mathrm{Si}$ & $\approx 1.8(\mathrm{~d})$ & $\approx 11$ & 3.32 \\
\hline $\mathrm{CdTe}$ & $1.45-1.5(\mathrm{~d})$ & 10.2 & 2.89 \\
\hline $\mathrm{CuInSe} 2(\mathrm{CIS})$ & $0.96-1.04(\mathrm{~d})$ & & \\
\hline $\begin{array}{c}\mathrm{A} 1 \mathrm{xGa} 1-\mathrm{xAs} \\
(0 \leq \mathrm{x} \leq 0.45)\end{array}$ & $1.424+1.247 \mathrm{x}(\mathrm{d})$ & $13.18-3.12 \mathrm{x}$ & \\
\hline $\begin{array}{c}\mathrm{A} 1 \mathrm{xGa} 1-\mathrm{xAs} \\
(0.45 \leq \mathrm{x} \leq 1)\end{array}$ & $1.9+0.125 \mathrm{x}+0.143 \mathrm{x}^{2}$ & & \\
\hline
\end{tabular}

These values are provided at the temperature of $300 \mathrm{~K}$. The values of bandgap are given with index $\mathrm{i}$ and $\mathrm{d}$ as indirect and direct respectively. The refractive index is given at the 
wavelength $590 \mathrm{~nm}(2.1 \mathrm{eV})$ unless otherwise stated. TEC stands for thermal expansion coefficient. Based on energy demand, PV cells are connected together in series to increase the voltage or in parallel to increase the current. Cells connected together produce a PV module, PV modules connected together produce an array and multiple arrays are connected to build a solar power plant as shown in Fig. 2.



Fig. 2. PV cell, Module and Array [3]

\section{PHOTOVOLTAIC CELL EFFICIENCY AND COST}

The efficiency of solar cells can be measure by their ability to convert solar energy into useful energy for human consumption. The ultimate and two nominal Shockley-Quiesser efficiencies for different semiconductor materials are shown in Fig. 3. The black-body radiation with temperature $\mathrm{T}=6000 \mathrm{~K}$ was used in keeping with the Shockley-Queisser work [5].

Solar cell efficiencies vary from $6 \%$ for amorphous siliconbased solar cells to $44.0 \%$ with multiple-junction concentrated photovoltaics [6] but the efficiency of commercial solar cells in the market is in the range of $14-22 \%$ [7] [8]. The most efficient solar cell so far was manufactured by Solar Junction in April 2011. This solar cell is a multi-junction concentrator solar cell with an efficiency of $43.5 \%$ [9].



Fig. 3. The 'ultimate' and two 'nominal' Shockley-Queisser efficiencies [5]

Sharp Corporation have achieved an efficiency of $35.8 \%$ in 2009, using a triple-junction manufacturing technology without concentrator [10]. The same design has been used also by Boeing Spectrolab to achieve an efficiency of $40.7 \%$. It is important to have efficient solar cells at less cost. The use of concentrator in solar cells manufacturing may reduce the cost of solar cell by concentrating up to 1,000 suns through magnifying lens onto a smaller sized photovoltaic cell. However, this leads to the overheat of solar cell and reduce of his efficiency and life that are decreasing with the increase of solar cell temperature. To operate, such concentrated solar power will require a sophisticated heat sink using passive cooling designs, otherwise the passive cooling will reduce the overall efficiency and economy by consuming a certain amount of energy require for his operation. The efficiency of PV system can also be improved by the use of hybrid PV thermal collectors (PV/T) systems. These systems combined PV cells which converts solar energy into electrical energy at about $14 \%$ to $22 \%$ and the remains of energy in form of heat is removed from the system by thermal absorber to cool the photovoltaic system and improve his efficiency. The capture of both electrical energy and removed heat for heating propose allow those systems to have higher exergy [11] and thus have higher overall energy efficiency than conventional solar photovoltaic or solar thermal [12] [13].

They have been many attempts to cut down the costs of solar cells and modules to make them both competitive and efficient. The energy conversion efficiency of the PV material need to be increased by improves their electrical, optical and structural properties by choosing semiconductor material with appropriate energy gap that matches the solar spectrum. Some materials that fit into different efficiency regimes are given in Table 2. Ultrahigh-efficiency devices $(\eta>30 \%)$ [14] are made by using $\mathrm{GaAs}$ and $\mathrm{GaInP}_{2}$ semiconductors with multijunction tandem cells. High-quality, single-crystal silicon materials are used to achieve high-efficiency cell $(\eta>20 \%)$. Organic photovoltaic cells (OPVs) are alternative solution to energy problems. In recent years, they have a net improvement of the power conversion efficiency ranges of OPVs from $3 \%$ to over $15 \%$ [15].

Table 2. The current best reported efficiencies of different types of solar cells [5]

\begin{tabular}{|c|c|c|c|}
\hline Solar Cells & $\begin{array}{c}\text { Efficiency } \\
(\%)\end{array}$ & $\begin{array}{c}\text { Current } \\
\text { Density } \\
\text { (mA/cm2) }\end{array}$ & $\begin{array}{c}\text { Open Circuit } \\
\text { Voltage (V) }\end{array}$ \\
\hline \multicolumn{4}{|c|}{ Crystalline: single junction } \\
\hline c-Si & 24.7 & 42.2 & 0.706 \\
\hline GaAs & 25.1 & 28.2 & 1.022 \\
\hline InP & 21.9 & 29.3 & 0.878 \\
\hline \multicolumn{4}{|c|}{ Crystalline: multijunction } \\
\hline $\begin{array}{c}\text { GaInP/GaAs/Ge } \\
\text { tandem }\end{array}$ & 31.0 & 14.11 & 2.548 \\
\hline \multicolumn{4}{|c|}{ Thin-film: single junction } \\
\hline CdTe & 16.5 & 25.9 & 0.845 \\
\hline CIGS & 18.9 & 34.8 & 0.696 \\
\hline \multicolumn{4}{|c|}{ Photoelectrochemical } \\
\hline $\begin{array}{c}\text { a-St/a-SiGe } \\
\text { tandem }\end{array}$ & 13.5 & 7.72 & 2.375 \\
\hline \multicolumn{4}{|c|}{11.0} \\
\hline $\begin{array}{c}\text { Dye-sensitised } \\
\text { TiO2 }\end{array}$
\end{tabular}

The best performance of photovoltaic systems is obtained when they face the sun. This can be achieved by increasing the time they face the sun by use of solar trackers with an increase of 
about $20 \%$ in winter season and an increase of $50 \%$ in summer season obtained. For static mounted systems, the sun paths must be analysis; modules are setting at a tilt angle equal to the latitude. The performance of this type of system can be improved by adjusting the tilt angle for winter and summer seasons.

Here are the top five best solar panel manufacturers in 2019 ranked based on the highest efficiency solar panel they have to offer: SunPower (22.8\%), LG (21.7\%), REC Solar $(21.7 \%)$, Panasonic (20.3\%) and Silfab (20.0\%) [16] and the top five the most efficient solar panels in 2019 ranked based on the efficiency of the product are: $X$ series : SPR-X22-370 by SunPower (22.70 \%), REC Alpha Series 380 AA by REC Solar (21.70 \%), LG NeON R by LG (21.10\%), HiDM-345MS by Canadian Solar (20.46 \%) and N340 HIT + Series by Panasonic $(20.30 \%)$ [17].

\section{APPLICATIONS AND ENVIRONMENTAL IMPACT OF PV TECHNOLOGY}

Solar systems are used in many areas such as power stations, buildings, transport, standalone devices, rural electrification, floatovoltaics, telecommunication and signaling, spacecraft applications as main suppliers of electrical energy as well as backup sources. World production of photovoltaic devices is allocated mostly to power stations, buildings, standalone and grid connected systems. Many utility-scale solar farms have been constructed all over the world. The world's largest photovoltaic power stations are given in Table 3 . This table gives the list of operating solar farms that are 1,000 MW or large.
The areas where the cost to connect to utility grid is higher have seen an increase in the use of solar powered remote fixed devices. Such applications include solar lamps, water pumps, parking meters, emergency telephones, trash compactors, temporary traffic signs, charging stations and remote guard posts and signals [13]. Building-integrated photovoltaics (BIPV) are actually more used into new domestic and industrial buildings as principal or auxiliary source of electrical energy [34]. In this design, the PV arrays are incorporated into the roof or walls of the building. Roof tiles with integrated PV cells are also common. PV systems have been considered as one of option to overcome environmental problems due to an increasing combustion of fossil fuels.

PV technologies have made important progress recently in terms of annual production capacity and life cycle environment performances, which requires the consideration of environmental impacts of such technologies. Different PV technologies show little variations in the emissions when compared the emissions from conventional energy technologies that replaced by the latest PV technologies [35]. The operation and maintenance of PV technology have a very low impact on the environment. Relative to burning coal, every gigawatt-hour of electricity generated by PV would prevent the emission of about 10 tons of $\mathrm{SO}_{2}, 4$ tons of $\mathrm{NOx}, 0.7$ tons of particulates (including $1 \mathrm{~kg}$ of Cd and $120 \mathrm{~kg}$ of As), and up to 1000 tons of $\mathrm{CO}_{2}$ [36]. The only major challenge of this technology to the environment is the emission of various toxic, flammable and explosive chemicals related to the process of manufacturing of the cells. Table 4 gives a summary of environmental, health and safety (EHS) issues pertaining to the manufacture of Crystalline$\mathrm{Si}(\mathrm{x}-\mathrm{Si})$, amorphous-silicon (a-Si), cadmium telluride (CdTe), copper indium diselenide (CIS), copper indium gallium diselenide (CGS) and gallium arsenide (GaAs), which are currently commercially available.

Table 3. World's largest photovoltaic power stations [18]

\begin{tabular}{|l|c|c|c|c|l|}
\hline \multicolumn{1}{|c|}{ Name } & Country & $\begin{array}{c}\text { Capacity } \\
{[\mathrm{MWp}]}\end{array}$ & $\begin{array}{c}\text { Land Size } \\
{[\mathrm{km} 2]}\end{array}$ & Year & \multicolumn{1}{|c|}{ Remarks } \\
\hline $\begin{array}{l}\text { Tengger Desert Solar } \\
\text { Park [19] }\end{array}$ & China & 1,547 & 43 & 2016 & $\begin{array}{l}1,547 \text { MW solar power was installed } \\
\text { in Zhongwei, Ningxia by 2015. }\end{array}$ \\
\hline $\begin{array}{l}\text { Bhadla Solar Park } \\
\text { [20] [21] [22] }\end{array}$ & India & 1,515 & 40 & 2019 & $\begin{array}{l}\text { The park is proposed to have a } \\
\text { capacity of 2,255 MW [23] to be } \\
\text { completed by December 2019. }\end{array}$ \\
\hline $\begin{array}{l}\text { Pavagada Solar Park } \\
\text { [24] [25] [26] [27] }\end{array}$ & India & 1,400 & 53 & 2019 & $\begin{array}{l}\text { In Karnataka state, total planned } \\
\text { capacity 2,050 MW }\end{array}$ \\
\hline $\begin{array}{l}\text { Noor Abu Dhabi [28] } \\
\text { [29] }\end{array}$ & UAE & 1,177 & 2019 & $\begin{array}{l}\text { Commercial operation achieved in } \\
\text { June 2019. Located at Sweihan. }\end{array}$ \\
\hline $\begin{array}{l}\text { Kurnool Ultra Mega } \\
\text { Solar Park [30] }\end{array}$ & India & 1,000 & 24 & 2017 & $\begin{array}{l}1000 \text { MW operational as of December } \\
2017\end{array}$ \\
\hline $\begin{array}{l}\text { Datong Solar Power } \\
\text { Top Runner Base [31] } \\
\text { [32] [33] }\end{array}$ & China & 1,000 & & 2016 & $\begin{array}{l}\text { 1 GW Phase I completed in June 2016. } \\
\text { Total capacity will be 3 GW in 3 } \\
\text { phases. }\end{array}$ \\
\hline
\end{tabular}


The actual hazard to health posed by these materials depends on their inherent toxicological properties, and the intensity, frequency, and duration of human exposures. The PV industry exercises continuing vigilance to minimize the risks of hazardous substances, and has adopted a pro-active, long-term environmental strategy to prevent potential environmental damage by products and processes [36].

Table 4. Major hazards in PV Manufacturing [37]

\begin{tabular}{|l|l|}
\hline Module Type & \multicolumn{1}{|c|}{ Types of Potential Hazards } \\
\hline x-Si & $\begin{array}{l}\mathrm{HF} \text { acid burns } \\
\mathrm{SiH}_{4} \text { fires/explosions } \\
\mathrm{Pb} \text { solder / module disposal }\end{array}$ \\
\hline $\mathrm{a}-\mathrm{Si}$ & $\mathrm{SiH}_{4}$ fires/explosions \\
\hline $\mathrm{CdTe}$ & $\begin{array}{l}\mathrm{Cd} \text { toxicity, carcinogenicity, module } \\
\text { disposal }\end{array}$ \\
\hline CIS, CGS & $\mathrm{H}_{2} \mathrm{Se}$ toxicity, module disposal \\
\hline GaAs & $\begin{array}{l}\text { AsH } \\
\text { flammability, module disposal }\end{array}$ \\
\hline
\end{tabular}

Life cycle analysis (LCA) referred also to as "cradle-to-grave" assessment aims to examine the environmental impact of a product throughout its life cycle have been practiced since 1970s. A regional life cycle sustainability assessment approach and its application on solar photovoltaic was performed on the solar PV system $4 \mathrm{kWp}$ wall mounted system on slanted roof with monocrystalline panels [38]. Five stages of life cycle of solar PV were considered in this study, including raw material requisition manufacturing, installation/construction, operation and decommissioning. The founding was that available solar radiation has direct impact on techno-economic and environmental sustainability of solar PV, hence this technology would be less suitable for regions with less incident sunlight. LCA was also performed to electricity generation assessment [39] [40], sustainability assessment [38] [41] and tracking systems assessment [42]. LCA results review of mono-Si PV systems, multi-Si PV systems, thin film amorphous silicon (aSi) PV systems, cadmium telluride thin film (CdTe) PV systems, copper indium selenide (CIS) PV systems, dye sensitized solar cells (DSSC) PV systems, perovskite solar cell (PSC) PV systems, quantum dot sensitized solar cell (QDSSC) PV system and more references on studies related to LCA of different PV technologies are found in [43].

With the growing demand of thin film module production to meet the demand in years to come, the life cycle assessment has to be done to evaluate the environment impacts from such technologies. Many publications have been made in the field of LCA applied to the thin film PV technologies and more references on full lifecycle and multi-impact assessment coverage and eco-design considerations of thin-film photovoltaic technologies can be found in [44].

In general, the contribution of the extraction of new material and their process to the total impact of PV cells was small compared to the impact from the consumption of electricity during the manufacturing. To reduce the environmental impact, the development of future PV technologies must focus more in the amelioration of their process and manufacturing.

\section{EVOLUTION OF PV CAPACITY AND ECONOMY}

Compare to 13 TW consumed in 2005 by humans, the sunlight reaching the surface of the Earth is almost 10000 times average [45] it can be seen conclude that in years to come, solar energy could become the primary source of energy. With a density of about $170 \mathrm{~W} / \mathrm{m}^{2}$, solar electrical generation has the highest power density compare to others renewable energy systems [45].

Solar PV are developing quickly. Early 2015, the worldwide installed solar PV increased to $200 \mathrm{GW}$, what is 40 times more than installed solar PV in 2006 [46]. With the total electrical power output capacity of 200 billion $\mathrm{kWh}$ in a calendar year, the world's PV capacity represents $1 \%$ of global electricity demand. The number of countries using solar PV is about 100 [47] [48]. Throughout the world, PV is actually the third most important RE source after hydro and wind based on installed capacity [1]. The estimation of European PV Industry Association (EPIA) projects PV to meet $10 \%$ to $15 \%$ of Europe's energy demand in 2030 [49] [50] by 2050, over $20 \%$ of electricity demand could be supplied by PV [51].

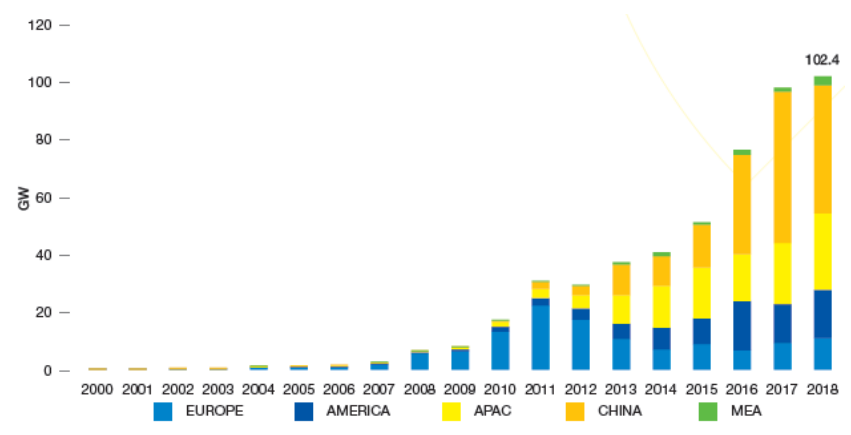

Fig. 4. Evolution of Global Annual Solar PV Installed Capacity 2000-2018 [52]

Compare to $97.5 \mathrm{GW}$ of total of annual solar PV installed capacity in 2017, PV installed capacity seen a growing of $4 \%$ year-on-year growth with $102.4 \mathrm{GW}$ installed in 2018 which is higher than many solar analysts had anticipated as seen in Fig. 4. This bring the global total solar PV installed capacity to 509.3 GW by the end of 2018, up from 407 GW in 2017 as seen in Fig. 5. This represents $25 \%$ of growth of the total installed PV power capacity.

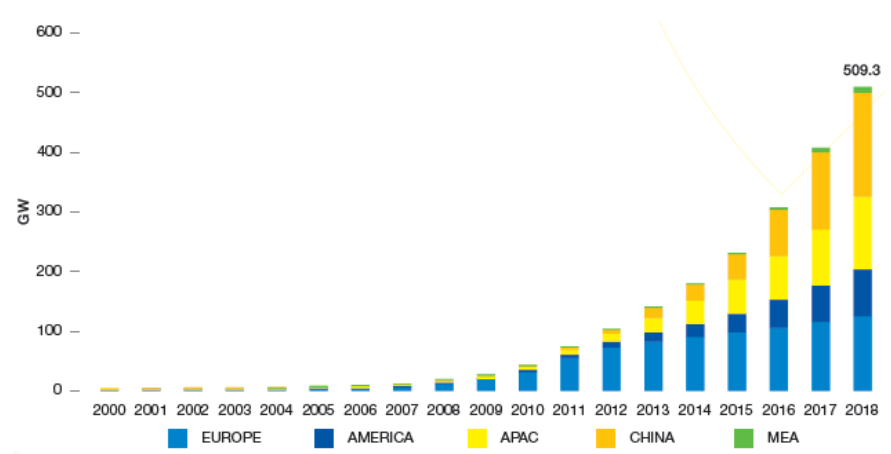

Fig. 5. Global Total Solar PV Installed Capacity 2000-2018 [52] 


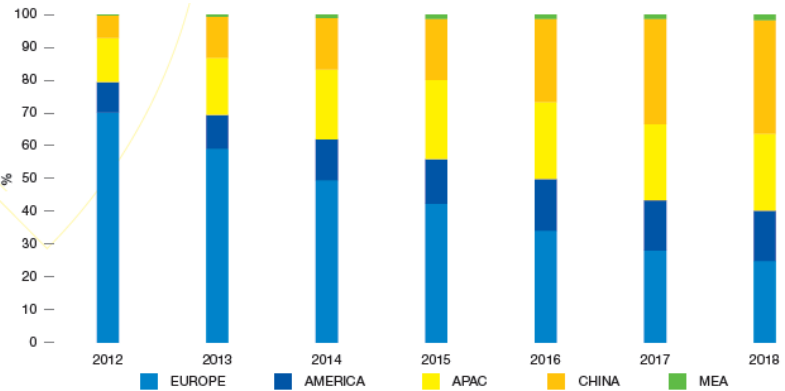

Fig. 6. Global Total Solar PV Installed Capacity Shares 2012-2018 [52]

Although even if the growth of Asian market slowed, the Asia pacific region (china included) extended its solar PV leadership in 2018 with more than about $58 \%$ global market share or a $3 \%$ points year-on-year growth which is more than half of the global power generation capacity [52] and can be noticed in Fig. 6. This is due to an additional $71.3 \mathrm{GW}$ in 2018 resulted in $295.7 \mathrm{GW}$ of total installed capacity. From Fig. 7 it can be noticed that the European market share lost with a dropped from $30 \%$ points to $25 \%$. Even so, European maintained its second position with a cumulative installed capacity of $78.2 \mathrm{GW}$ and a $15 \%$ stake while fourth position is held by the middle east and Africa (MEA) with a total solar capacity of $9.6 \mathrm{GW}$ representing $1.9 \%$ which is a slight growth from $1.7 \%$ in 2017 . Those results are represented in Table 5.

\section{Global Total Solar PV Installed} Capacity 2018

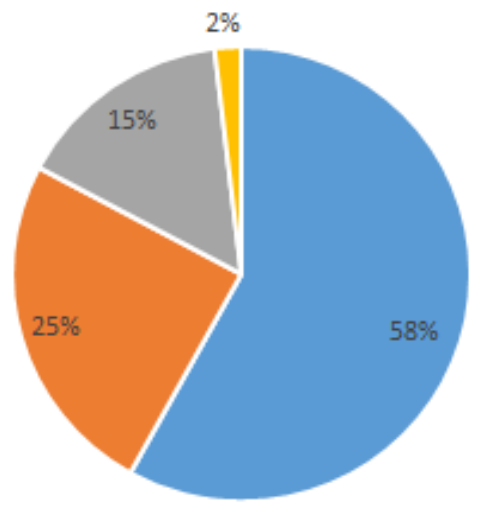

- APAC (China included) = Europe = America = MEA

Fig. 7. Global Total Solar PV Installed Capacity 2018

Table 5. Results of global total solar PV capacity shares in 2018

\begin{tabular}{|l|c|}
\hline \multicolumn{1}{|c|}{ Region } & $\begin{array}{c}\text { Capacity } \\
\text { shares [GW] }\end{array}$ \\
\hline APAC + China & 295.7 \\
\hline Europe & 125.8 \\
\hline America & 78.2 \\
\hline MEA & 9.6 \\
\hline Total & 509.3 \\
\hline
\end{tabular}

Driven by the advance of technology, the production at industrial scale and the sophistication, the price of PV have fallen severally from the first cells produced [53] [54] and the levelised cost of electricity (LCOE) of the PV have become competitive against the conventional electricity sources for an expend geographic regions [55]. Since 2008, the price of the PV has considerably felt. For the crystalline silicon solar cell for example, the price have fallen from $\$ 76.67 / \mathrm{W}$ in 1977 to an estimation of $\$ 0.74 / \mathrm{W}$ in 2013 [56] what is an evidence confirming Swanson's law what is a similar observation to famous DeMoore law which stipule that the solar cell price decrease by $20 \%$ each time the industrial capacity is double [56]. An average price of solar cells presented by Solarbuzz group was from $\$ 3.50 / \mathrm{W}$ to $2.43 / \mathrm{W}$ by 2011 [57]. From summer 2008 to 2011 , the price of solar panels has fallen by $60 \%$ based on Bloomberg New Energy Finance estimation, putting solar power on the same level of competition with the retail price of electricity in many higher insolation countries. Another alternative and consistent image of the falling of the price of electricity by $75 \%$ from 2007 to 2012 was published [58] without specify if the figure was only for Unit States or global. The RE energy technology is becoming more and cheaper while fossil fuels price generally increases more and more. For large scale installations, the prices below $\$ 1.00 / \mathrm{W}$ have been reached. In April 2012, the price of $€ 0.60 / \mathrm{W}$ (an equivalent to $\$ 0.78 / \mathrm{W}$ ) for a panel has been published for a large scale five years market [59]. By the end of 2012, the best class of module felt to $\$ 0.50 / \mathrm{W}$ and expects to fall to $\$ 0.36 / \mathrm{W}$ by 2017 [60].

The PV installations can operate until 100 years or more [61] with just a little of maintenance or intervention after their startup, that means that the operating cost for any PV power plant is very low compare to the existent technologies. As low is the solar energy price as favourable it is compared to conventional energy, as more it is attractive to utilities and users. A small budget is allocated to the research for the development of solar cells compare to fossil and nuclear energy; It reveals a great possibility to improve PV. However, concentrating PV cells with very higher efficiency of about $40 \%$ are already at the experimental stage [62] and the efficiency is increasing rapidly while the price of quantity produced fall rapidly [63]. The technology advance, the amelioration of manufacturing process and the industrial re-structuration let promise a future decrease of price of PV for years to come [53].

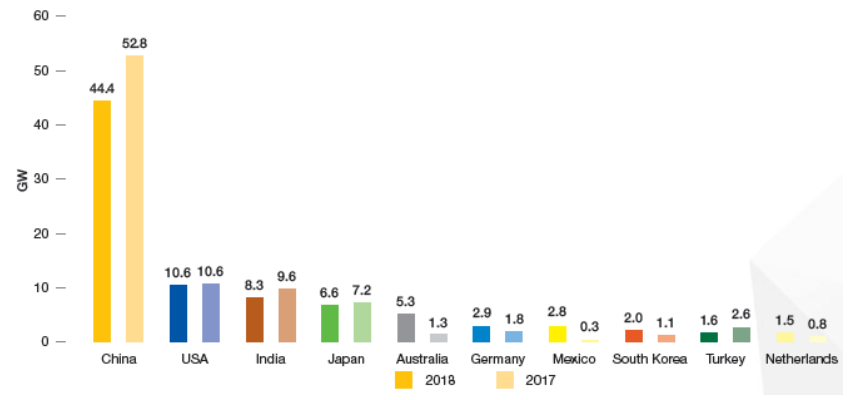

Fig. 8. Global Top 10 Solar PV Markets in 2018 [52]

With a decline of $16 \%$ in 2018, the global solar PV market continue to be dominated by China with $44.4 \mathrm{GW}$ installed in 2018 against $52.8 \% \mathrm{GW}$ in 2017. This drop down is due to China's solar restructuring of its incentives scheme to make 
solar fit for the next growth phase [52]. From the global top 10 market represent in Fig. 8, China has contributed with $60 \%$ and $52 \%$ in 2017 and 2018 respectively representing a drop of $8 \%$ as seen in Fig. 9 and Fig. 10. Nevertheless, China continues to add more solar than the remaining top 10 combined.

\section{Global Top 10 Market in 2017}

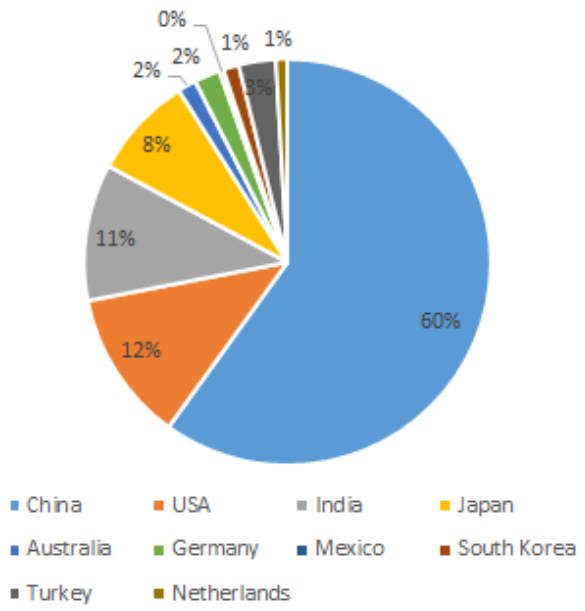

Fig. 9. Global Top 10 Market in 2017

\section{Global Top 10 Market in 2018}

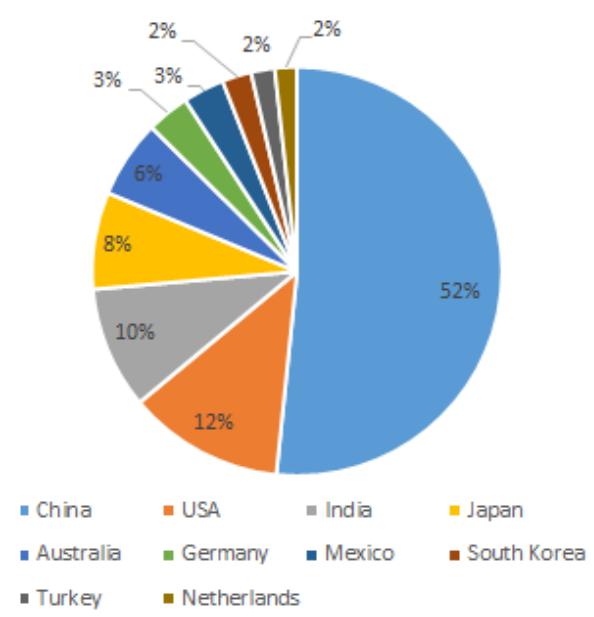

Fig. 10. Global Top 10 Market in 2018

The 2018 solar PV outlook market forecast presents a growth of solar market with progressive slow down, from 2019 to 2023 over 5 years. The global market outlook (GMO) 2018 in the medium scenario anticipates around $128.4 \mathrm{GW}$ of newly installed PV capacity in 2019 representing $25 \%$ market growth in 2018. The low scenario estimates a strong demand drop to 84.5 GW while the high scenario forecasts up to $165.4 \mathrm{GW}$ of solar additions in 2018 as represented in Fig. 11. Those will depend on when and how China will come back in the market [52].

From Fig. 12, the scenarios of the GMO 2019 show high growth for world total solar PV market scenarios 2019-2023. The estimated cumulative installed capacity is $645 \mathrm{GW}$ for the medium scenario 2019. From the 5 years GMO from 2019 to 2023 , the production is that the global solar power generation plant capacity will reach $1297 \mathrm{GW}$ in 2023 for medium scenario. The high scenario predicts a global solar power generation plan capacity of $1610 \mathrm{GW}$ by the end of 2023 while the low scenario predicts $1043.6 \mathrm{GW}$. Based on the predictions, the world could centre the Tetrawatt production capacity level by 2021, only 3 years after reaching $0.5 \mathrm{TW}$ level [52].

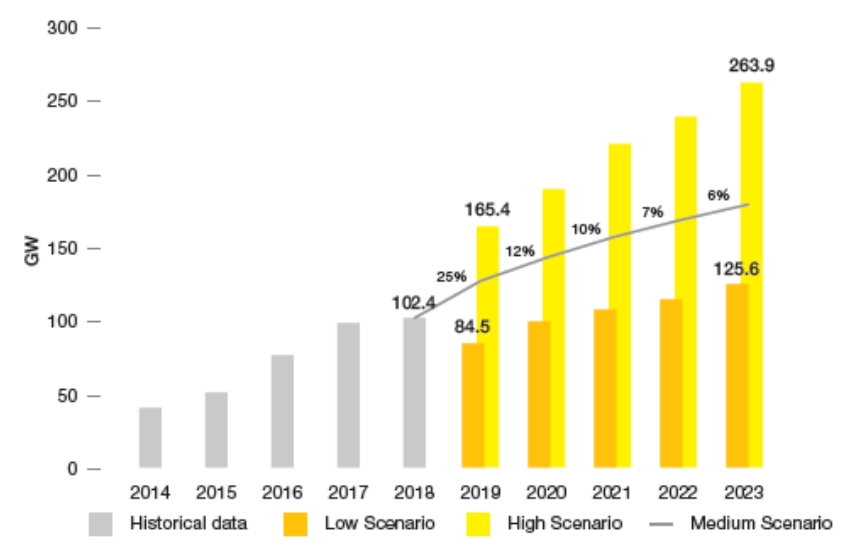

Fig. 11. World Annual Solar PV Market Scenarios 2019-2023 [52]

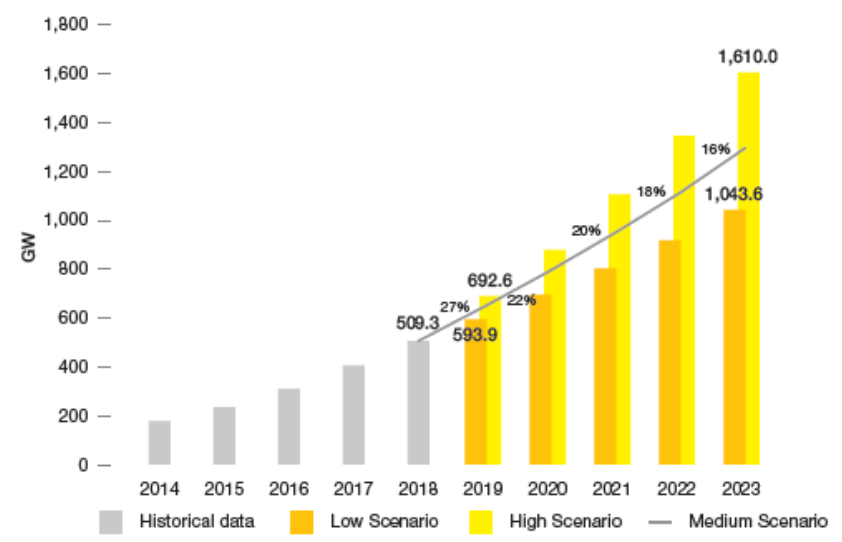

Fig. 12. World Total Solar PV Market Scenarios 2019-2023 [52]

\section{CONCLUSION}

The global total solar PV installed capacity 2018 is dominated by APAC (China included) with $58 \%$ of solar PV installed capacity, follows by Europe (25\%), America (15\%) and MEA ( $2 \%)$. Driven by the advance of technology, the production at industrial scale and the sophistication, the price of photovoltaics has fallen severally from the first cells produced and the levelised cost of electricity (LCOE) of the PV have become competitive against the conventional electricity sources for an expend geographic regions. After hydro and wind, the PV has become actually the third most important renewable energy source considering the total installed capacity.

The PV installations can operate until 100 years or more with just a little of maintenance or intervention after their start-up, that means that the operating cost for any PV power plant is very 
low compare to the existent technologies. As low is the solar energy price as favourable, it is compared to conventional energy, as more it is attractive to utilities and users. A small budget is allocated to the research for the development of solar cells compare to fossil and nuclear energy; it reveals a great possibility to improve photovoltaics. The technology advance, the amelioration of manufacturing process and the industrial restructuration let promise a future decrease of price of photovoltaics for years to come. The contribution of the extraction of new material and their process to the total impact of PV cells was small compared to the impact from the consumption of electricity during the manufacturing. To reduce the environmental impact, the development of future PV technologies must focus more in the amelioration of their process and manufacturing.

Even with a decline of $16 \%$ in 2018 , the global solar PV market continue to be dominated by China with $44.4 \mathrm{GW}$ installed in 2018 against $52.8 \%$ GW in 2017. The 2018 solar PV outlook market forecast presents a growth of solar market with progressive slow down, from 2019 to 2023 over 5 years. Based on the predictions, the world could centre the Tetrawatt production capacity level by 2021 , only 3 years after reaching 0.5 TW level.

\section{REFERENCES}

[1] G. Masson, M. Latour and D. Biancardi, "Global Market Outlook for Photovoltaics until 2016," EPIA-Europian Photovoltaic Industry Association, 2012.

[2] "Photovoltaic Effect," Mrsolar, 12 December 2010. [Online]. Available: http://www.mrsolar.com/photovoltaic-effect/. [Accessed 1306 2015].

[3] G. M. Masters, Renewable and efficient electric power systems, John Wiley and Sons Inc Publication, 2004.

[4] M. Z. Jacobson, "Review of solutions to global warming, air pollution, and energy security," Energy and Environmental Science, vol. 2, pp. 148-173, 2009.

[5] T. Markvart and L. Castafier, Practical Handbook of Photovoltaics: Fundamentals and Applications, Elsevier, 2003, pp. 97-132.

[6] UDaily, "UD-led team sets solar cell record, joins DuPont on \$100 million project," University of Daware, [Online]. Available: http://www.udel.edu/PR/UDaily/2008/jul/solar072307.h tml. [Accessed 1306 2015].

[7] O. Schultz, A. Mette, R. Preu and S. W. Glunz, "Silicon Solar Cells with Screen-Printed Front Side Metallization Exceeding 19\% Efficiency: The compiled state-of-the-art of PV solar technology and deployment," in European Photovoltaic Solar Energy Conference, Milan, 2007.

[8] Z. Shahan, "Sunpower Panels Awarded Guinness World Record," 20 June 2011. [Online]. Available: http://www.reuters.com/article

/2011/06/20/idUS110444863620110620. [Accessed 13 06 2015].

[9] E. Wesoff, "Update: Solar Junction Breaking CPV Efficiency Records, Raising \$30M,” 15 April 2011. [Online].

Available: http://www.greentechmedia.com/articles/read/solarjunction-setting-new-cpv-efficiency-records.

[10] Sharp, "Sharp Develops Solar Cell with World's Highest, Conversion Efficiency of 37.9\%," Sharp Corporation, [Online]. Available: http://sharpworld.com/corporate/news/130424.html. [Accessed 13 06 2015].

[11] A. Mojiri, R. Taylor, E. Thomsen and G. Rosengarten, "Spectral beam splitting for efficient conversion of solar energy - A review," Renewable and Sustainable Energy Reviews, vol. 28, pp. 654-663, 2013.

[12] M. J. M. Pathak, P. G. Sanders and J. M. Pearce, "Optimizing limited solar roof access by exergy analysis of solar thermal, photovoltaic, and hybrid photovoltaic thermal systems," Applied Energy, vol. 120, pp. 115124, 2014.

[13] N. M.-A. Mutombo, F. Inambao and R. Tiako, DEVELOPMENT OF NEURO-FUZZY CONTROL STRATEGIES FOR HYBRID PHOTOVOLTAIC FUEL CELL SYSTEMS, Delhi: Research India Publication, 2017.

[14] S. K. Deb, "Recent Developments in High-Efficiency PV Cells," in World Renewable Energy Congress VI, Brighton, U.K, 2000.

[15] J. Yu, Y. Zheng and J. Huang, "Towards High Performance Organic Photovoltaic Cells: A Review of Recent Development in Organic Photovoltaics," Polymers, vol. 6, pp. 2473-2509, 2014.

[16] V. Aggarwal, "What are the most efficient solar panels on the market? Solar panel efficiency explained, energysage: Smarter energy decisions," 1 July 2019. [Online]. Available: https://news.energysage.com. [Accessed 13 August 2019].

[17] I. Carlos, "The 20 Most Efficient Solar Panels of 2019," 0812 2019. [Online]. Available: https://ecotality.com. [Accessed 1509 2019].

[18] Wikipedia the free encyclopedia, "List of photovoltaic power stations," Wikipedia the free encyclopedia, [Online]. Available: https://en.wikipedia.org/wiki/List_of_photovoltaic_pow er_stations. [Accessed 21 September 2019].

[19] J. F. Weaver, "10 really cool Solar Power installations in (and above) the world," 30 January 2018. [Online]. Available: https://electrek.co/2018/01/29/10-really-coolsolar-power-installations/. [Accessed 13 July 2019]. 
[20] H. K. Singh, “Country's Biggest Solar Park In Rajasthan, At The Heart Of India's Clean Energy Push," 21 May 2017. [Online]. Available: https://www.ndtv.com/indianews/countrys-biggest-solar-park-at-the-heart-of-indiasclean-energy-push-1696271. [Accessed 21 June 2019].

[21] The Times of India, "Solar plants of $620 \mathrm{MW}$ get operational at Bhadla park. Archived 2018-11-03 at the Wayback Machine. „” 02 October 2018. [Online]. Available:

https://timesofindia.indiatimes.com/city/jaipur/solarplants-of-620-mw-get-operational-at-bhadlapark/articleshow/66035558.cms. [Accessed 12 August 2019].

[22] ETEnergyWorld, "Azure Power commissions $150 \mathrm{Mw}$ solar project in Rajasthan," 29 April 2019. [Online]. Available:

https://energy.economictimes.indiatimes.com/news/rene wable/azure-power-commissions-150-mw-solar-projectin-rajasthan/69099360. [Accessed 22 August 2019].

[23] PV Tech, "SECI tenders another 750MW at record-luring Bhadla Solar Park," 22 March 2018. [Online]. [Accessed 18 September 2019].

[24] S. Prateek, "Karnataka's Pavagada Solar Park to be Fully Operational by December 2019,” 12 April 2019. [Online]. Available: https://mercomindia.com/pavagadasolar-park-operational-december-2019/.

[25] S. Prateek, "600 MW of Solar Projects Synchronized to The Grid at Karnataka's Pavagada Park," 18 February 2018. [Online]. Available: https://mercomindia.com/600mw-grid-sychronizedpavagada/. [Accessed 23 August 2019].

[26] The Hindu, "Pavagada solar park inaugurated," 2 March 2018. [Online]. Available: https://www.thehindu.com/news/national/karnataka/pav agada-solar-park-inaugurated/article22898627.ece. [Accessed 18 September 2019].

[27] "ReNew Power Commissions 300 MW Solar Plant in Pavagada," 10 April 2019. [Online]. Available: https://www.business-standard.com/article/ptistories/renew-power-commissions-300-mw-solar-plantin-pavagada-119041000686_1.html. [Accessed 20 September 2019].

[28] The National, "Noor Abu Dhabi solar plant begins commercial operation," 30 June 2019. [Online]. Available: https://www.thenational.ae/uae/environment/noor-abudhabi-solar-plant-begins-commercial-operation1.880723

[29] J. Parnell, "World's Largest Solar Power Plant Switched On," 30 June 2019. [Online]. Available: https://www.forbes.com/sites/johnparnell/2019/06/29/w orlds-largest-solar-power-plant-switched- on/\#4f588f01161a. [Accessed 22 September 2019].

[30] A. Jaiswal and L. Bhagavatula, "The World's Largest Solar Park - Kurnool, India," 1 November 2017. [Online]. Available: https://www.nrdc.org/experts/anjali-jaiswal/worldslargest-solar-park-kurnool-india. [Accessed 22 September 2019].

[31] PockerJoker, “Ofweek," 1806 2018. [Online]. Available: https://solar.ofweek.com/2017-02/ART-260009-812030106500.html. [Accessed 20 September 2019].

[32] China Energy Storage Network News, "Shanxi Daily," 20 May 2017. [Online]. Available: www.escn.com.cn. [Accessed 18 August 2019].

[33] C. Lin, "China's Top Runner Program Improves Mono-si Products' Market Share to 25\% EnergyTrend PV," 20 May 2017. [Online]. Available: https://pv.energytrend.com/research/China_Top_Runner _Program_Improves_Mono_si_Products_Market_Share _to_25_percent.html.

[34] Wisconsin Public Service Corporation, "Building Integrated Photovoltaics," [Online]. Available: http://www.buildingsolar.com. [Accessed 1306 2015].

[35] V. M. Fthenakis, H. C. Kim and E. Alsema, "Emissions from Photovoltaic Life Cycles," Environmental Science \& Technology, vol. 42, no. 6, pp. 2168-2174, 2008.

[36] V. M. Fthenakis and P. D. Moskowitz, "Photovoltaics: Environmental, Health and Safety Issues and Perspectives," Progress in Photovoltaics: Research and Applications, vol. 8, pp. 27-38, 2000.

[37] V. M. Fthenakis, T. Markvart and L. Castaner, "Practical Handbook of Photovoltaics: Fundamentals and Applications," Elsevier, 2003.

[38] T. Li, A. P. Roskilly and Y. Wang, "A Regional Life Cycle Sustainability Assessment Approach and its Application on Solar Photovoltaic," in The 8th International Conference on Applied Energy ICAE2016, 2017.

[39] W. Luo, Y. S. Khoo, A. Kumar, J. S. C. Low, Y. Li, Y. S. Tan, Y. Wang, A. G. Aberle and S. Ramakrishna, "A comparative life-cycle assessment of photovoltaic electricity generation in Singapore by multicrystalline silicon technologies," Solar Energy Materials and Solar Cells, vol. 174, pp. 157 - 162, 2018.

[40] A. F. Sherwani, J. A. Usmani and Varun, "Life cycle assessment of solar PV based electricity generation systems: A review," Renewable and Sustainable Energy Reviews, vol. 14, pp. 540 - 544, 2010.

[41] T. Li, A. P. Roskilly and Y. Wang, "Life cycle sustainability assessment of grid-connected photovoltaic power generation: A case study of Northeast England," 
Applied Energy, vol. 227, pp. 465 - 479, 2018.

[42] J. Antonanzas, M. Arbeloa-Ibero and J. C. Quinn, "Comparative life cycle assessment of fixed and single axis tracking systems for photovoltaics," Journal of Cleaner Production, vol. 240, pp. 1-12, 2019.

[43] N. A. Ludin, N. I. Mustafa, M. M. Hanafiah, M. A. Ibrahim, M. A. M. Teridi, S. Sepeai, A. Zaharim and K. Sopian, "Prospects of life cycle assessment of renewable energy from solar photovoltaic technologies: A review," Renewable and Sustainable Energy Reviews, vol. 96, pp. $11-28,2018$.

[44] M. D. Chatzisideris, N. Espinosa, A. Laurent and F. C. Krebs, "Ecodesign perspectives of thin-film photovoltaic technologies: A review of life cycle assessment studies," Solar Energy Materials \& Solar Cells, vol. 156, p. 2-10, 2016.

[45] V. Smil, "Energy at the Crossroads," in OECD Global Science Forum Conference on Scientific Challenges for Energy Research, Paris, 2006.

[46] T. Hunt, "The Solar Singularity Is Nigh," Greentech Media, 09 March 2015.

[47] G. Masson and M. Brunisholz, "A Snapshot of Global PV Markets 1992-2014," IEA - International Energy Agency, 2015.

[48] D. Barnes, E. Martinot, A. McCrone, J. Roussell, J. L. Sawin, R. Sims and V. S. O‘Brien, "Renewables 2011: Global Status Raport," REN21, 2011.

[49] EPIA-European Photovoltaic Industry Association, "Market Report 2013 (For EPIA Members only)," EPIA - European Photovoltaic Industry Association, 2014.

[50] G. Masson, M. Latour, M. Rekinger, I.-T. Theologitis and M. Papoutsi, "Global Market Outlook for Photovoltaics 2013-2017," EPIA-European Photovoltaic Industry Association, 2013.

[51] I. Wilhelm and S. Teske, "Solar Photovoltaic Electricity Empowering the World," EPIA - Europian Photovoltaic Industry Association, 2011.

[52] M. Schmela, A. Beauvais, N. Chevillard, M. G. Paredes, M. Heisz and R. Rossi, "Global Market Outlook For Solar Power 2019 - 2023," SolarPower Europe, 2019.

[53] M. Bazilian, I. Onyeji, M. Liebreich, I. MacGill, J. Chase, J. Shah, D. Gielen, D. Arent, D. Landfear, D. Landfea and S. Zhengrong, "Re-considering the economics of photovoltaic power," Renewable Energy, vol. 53, pp. 329-338, 2013.

[54] R. M. Swanson, "Photovoltaics Power Up," Science Magazine, vol. 324, no. 5929, pp. 891-892, 15052009.

[55] K. Branker, M. J. M. Pathak and J. M. Pearce, "A review of solar photovoltaic levelized cost of electricity,"
Renewable and Sustainable Energy Reviews, vol. 15, pp. 4470-4482, 2011.

[56] G. Carr, "Sunny Uplands: Alternative energy will no longer be alternative," 2111 2012. [Online]. Available: http://www.economist.com/news/21566414-alternativeenergy-will-no-longer-be-alternative-sunny-uplands. [Accessed 2006 2015].

[57] J. Quiggin, "The End of the Nuclear Renaissance," 301 2012. [Online]. Available: http://nationalinterest.org/commentary/the-end-thenuclear-renaissance-6325. [Accessed 2006 2015].

[58] K. Wells, "Solar Energy Is Ready. The U.S. Isn't," 2510 2012. [Online]. Available: http://www.bloomberg.com/bw/articles/2012-1025/solar-energy-is-ready-dot-the-u-dot-s-dot-isnt. [Accessed 2006 2015].

[59] SolarServer, "Chinese PV producer Phono Solar to supply German system integrator Sybac Solar with 500 MW of PV modules," Solar Magazine, 2012. [Online]. Available: http://www.solarserver.com/solarmagazine/solar-news/archive-2012/2012/kw18/chinesepv-producer-phono-solar-to-supply-german-systemintegrator-sybac-solar-with-500-mw-of-pvmodules.html. [Accessed 1607 2015].

[60] N. Rinaldi, "Solar PV Module Costs to Fall to 36 Cents per Watt by 2017," GreenTechSolar, 18062013. [Online]. Available: http://www.greentechmedia.com/articles/read/solar-pvmodule-costs-to-fall-to-36-cents-per-watt. [Accessed 15 04 2015].

[61] Hi Energy People, "Advantages and disadvantages of solar energy," Hi Energy People, [Online]. Available: http://www.hienergypeople.com/advantages-anddisadvantages-of-solar-energy/. [Accessed 2706 2015].

[62] Fraunhofer Institute for Solar Energy Systems ISE, "41.1\% efficiency multi-junction solar cells," 2801 2009. [Online]. Available: http://www.renewableenergyfocus.com/view/753/fraunh ofer-41-1-efficiency-multi-junction-solar-cells/. [Accessed 2706 2015].

[63] U. Bossel, "Does a Hydrogen Economy Make Sense?," in The IEEE, 2006. 